

Research Article

\title{
Petrogenesis, geochemistry and structural evidence of the neoproterozoic Pan-African orogenic event in Ghana, West Africa
}

\author{
Joana A. A. Darko' $\cdot$ Isaac Ahenkorah² ${ }^{2} \cdot$ Mathias N. Aakyiir ${ }^{3}$
}

C Springer Nature Switzerland AG 2019

\begin{abstract}
Certain parts of Ghana (Eastern and Volta region) are predominantly covered by neoproterozoic Dahomeyide rocks which occurred during the Pan-African Orogeny event in West Africa. To understand the petrological, geochemical and structural evidence of this geologic event, a detailed geological mapping exercise was conducted in some parts of the Eastern and Volta regions of Ghana. The aim of this research is to understand the local geology of these areas and how it best fits the regional geology of Ghana and its implications in the Pan-African Orogenic event. The evidences presented in this study show that the rocks in these areas are mainly metamorphic, which are granitic augen gneiss, biotite gneiss and quartzite. The gneisses were proposed to belong to the basement Dahomeyan, while the quartzites belong to the Togo Structural Unit. It was also inferred that the rocks have been deformed mainly by brittle and ductile deformation, resulting in structures such as foliations, fractures and joints observed in the quartzites and gneisses within the area of study. The structures within the study area have a general attitude of north-east-south-west with some few structures trending in the north-west-south-east directions. Again, it was inferred that the rocks from the Dahomeyan structural unit are highly metamorphosed and deformed as compared to the rocks from the Togo structural unit. The granitic augen gneiss and biotite gneiss have rock-forming minerals such as biotite, K-feldspar, quartz, muscovite, plagioclase and hornblende in varying proportions, whereas the quartzites are predominantly composed of glassy quartz crystals.
\end{abstract}

Keywords Pan-African · Orogenic · Petrology · Geochemistry · Structures · Gneiss · Quartzite

\section{Introduction}

The study area comprises local communities in the Eastern and Volta regions of Ghana and includes Frankadua, Apeguso and its surrounding areas. These areas lie within the Dahomeyide which is made up of three different formations, namely the Dahomeyan belt, Togo Structural Unit and the Buem Structural Unit. These formations resulted from the Pan-African Orogeny that occurred about 600 million years ago [1, 2]. The presence of geological structures and features found in these areas was influenced mainly by plate tectonics according to Dewey et al.
$[3,4]$. Plate tectonics describe the lithospheric movement over the plastic mantle resulting in several geological phenomena such as magmatism, formation of sedimentary basins and accretion of continental masses. According to Attoh et al. [5], the Pan-African Dahomeyide belt represents the south-western segment of the Trans-Saharan mobile belt along which the West African Craton was incorporated into western Gondwana. This was followed by anatectic doming and wrench faulting which is evident in rocks found in the south-eastern part of Ghana [6]. One of such events is the Pan-African Orogeny which resulted in the formation of a Supercontinent Gondwana around

\footnotetext{
$\triangle$ Isaac Ahenkorah, isaac.ahenkorah@mymail.unisa.edu.au | 'Department of Earth Science, University of Ghana, Legon, Accra, Ghana. ${ }^{2}$ School of Natural and Built Environments, University of South Australia, Adelaide, SA 5095, Australia. ${ }^{3}$ School of Engineering, University of South Australia, Adelaide, SA 5095, Australia.
} 
600 million years ago [7]. The south-eastern part of Ghana is a geologically complex area due to the various orogenic activities that took place in the area and can be manifested by the rocks found in the area. The quartzites and gneisses observed in the study area exhibited high degree of metamorphism and deformation which is an indication of the orogenic and collisional activities which occurred during the Pan-African Orogeny. Some parts of the study area had the Togo rocks bordering the Dahomeyan at the eastern end of the West African Craton. Rocks believed to be from the Togo Structural Unit occupied most of the highlands with the proposed Dahomeyan gneisses occupying the lowland areas within the study area. These rocks are highly deformed, tectonised, sheared and metamorphosed. Over the years, these areas have been mapped on a regional scale by most geologists. However, several assumptions have been made by previous researchers on the geological interpretations of the geologic or tectonic events that occurred in these areas due to the fact that previous mapping activities have been done on a regional scale. Therefore, this research aims to identify the lithologic units forming the local geology of the study area and their possible deformational history. Furthermore, information on petrology, geochemistry and structural signatures obtained in this study will be used to infer the geological history, as well as their stratigraphic correlation.

\section{Geologic setting}

There are five geological domains in Ghana which include (a) the western units found at the eastern margin of the West African Craton, (b) the Precambrian mobile belt units located in the south-eastern parts of Ghana, (c) the Voltaian sediments found in the central parts of Ghana, (d) the coastal sediment basins and (e) the Tertiary to Recent deposits $[8,9]$. The extensive orogenic event called the Neoproterozoic PanAfrican Orogeny is one of the greatest to have been recorded in the earth's history. The Pan-African Orogeny is an event which occurred about 600 million years ago and has affected large areas encircling the West African, Congo and Kalahari cratons [10]. The integration and shape of the African plate was affected by the tectonothermal Neoproterozoic PanAfrican Orogenic event (Fig. 1a). During this event, a number of mobile belts experienced intense deformation, migmatisation and metamorphism which constituted the final part of the orogenic cycle [11, 12]. The extent of the Pan-African Orogenic event geographically recounts that it is not just a single orogeny but a protracted orogenic cycle which involves ocean opening and closure as well as collision and accretion of crustal blocks [11, 12]. This orogenic event also resulted in the Trans-Saharan belt of about $2000 \mathrm{~km}$ long located at the eastern margin of the West African Craton
$[13,14]$. The study area falls within the south-eastern segment of the Trans-Saharan belt which is exposed in Burkina Faso, Niger, Togo, Benin and the south-eastern parts of Ghana which make up the Dahomeyide Orogenic belt. The Dahomeyide Orogen (Fig. 1b) in West Africa is interpreted to have formed by the collision of exotic blocks with the passive continental margin of the West African Craton. This collision and suture of the Dahomeyide Orogen onto the West African Craton resulted in the nappe stacking and crustal imbrication associated with the belt. The Dahomeyide is made up of three different formations, namely the Dahomeyan belt, Togo Structural Unit and the Buem Structural Unit.

\section{Materials and methods used}

Geological field mapping and laboratory studies including thin-section preparation, petrographic analysis, structural analysis and geochemical analysis of the rock samples were conducted in this study. Five rock samples consisting of two quartzites (J01 and J02) and three gneisses (J04, J05 and J06) were selected and labelled for petrographic (thinsection) analysis. Thin sections made from each sample were observed under the petrographic microscope. Photomicrographs of the various thin sections were also taken with the aid of the AMSCOPE software. Also, six samples were prepared, and cubes were cut out of each sample for geochemical data analysis. These samples included three quartzites (J01, J02 and J03) and three gneisses (J04, J05 and J06) as shown in Fig. 2. The geochemical analysis was conducted at the ALS geochemistry laboratory in Vancouver, Canada. Geochemical analysis done on the samples covers the major and trace elemental compositions of the rock. The major and trace elemental concentrations in the samples were measured using the inductively coupled plasma mass spectrometry (ICP-MS) and the multi-element fusion inductively coupled plasma atomic emission spectrometry (ICP-AES). Results obtained from the various analyses were corrected for spectral inter-element interferences (ALS laboratory) with precision greater than $2 \%$. Geo-Orient was used for structural analysis. The structural data from Microsoft Excel were exported into Geo-Orient and plotted as rose diagrams and poles. Deltagraph and Geochemical Data Toolkits (GCDkit 2.3) were used for plotting discriminant and bivariate plots for geochemical results obtained from the rock samples.

\section{Results and discussion}

\subsection{Field observations and petrographic analyses}

The metamorphic rocks found in the study area are mainly granitic augen gneiss, biotite gneiss and quartzites. 




Fig. 1 a A tectonic map of north-western Africa showing the two main West African Craton domains, after Feybesse and Milési [32]. b A map of the Dahomeyide orogenic belt in south-eastern Ghana showing the location of the study area, after Attoh [33]

Detailed field descriptions and petrographic analysis through thin section have been conducted on the quartzites and gneisses found in the study area and will be presented and discussed in the subsequent sections. The quartzites are the dominant rocks found in the study area, and they occupy about $70 \%$ of the outcrop map. The quartzites are mostly massive outcrops with medium to coarse-grained textures in areas such as Aboasa and some places in Frankadua. The quartzites have a mixture of grain sizes (well graded) in places such as the mountains at Apeguso (Fig. 3a). The quartzites at other places within the study area have quartz veins healing the fractures within the rock (Fig. 3b).

Thin-section observations made with the aid of the petrographic microscope indicate that the quartz grains are colourless in plane-polarised light. The rocks are medium to coarse grained in texture. The quartz grains are mainly well sutured due to coalescence followed by recrystallisation (Fig. 4a). The quartz grains have yellowish colouration which may be due to the thicker size of the thin section and exhibit undulose extinction due to strain with low to medium relief. These grains which are rounded (porphyroblast) large crystals formed during metamorphism in solid state are composed predominantly of quartz (Fig. 4b). The rounded crystals are quartz, lithic fragments from preexisting rocks that have been transported to the site where metamorphism begins. Hence, the rounded crystals are surrounded by the recrystallised sutured quartz grains. The gneisses observed are of two types, namely granitic augen gneiss (Fig. 5a) and biotite gneiss (Fig. 5b). The granitic augen gneiss is weathered and dark grey in colour. The rock has iron-stained surfaces with brown to pink colouration due to the weathering. The granitic augen gneiss has granitic veins (Fig. $5 \mathrm{C}$ ). It has prominent head and tail feldspar crystals called augens. The banding in the gneiss is less prominent but could be inferred based on the lighter and dark mineral segregation (Fig. $5 \mathrm{~d}$ ). The granitic augen gneiss has exfoliations which resulted from expansion and fracturing followed by weathering. The exfoliations are parallel to the banding in the granitic augen gneiss. The 


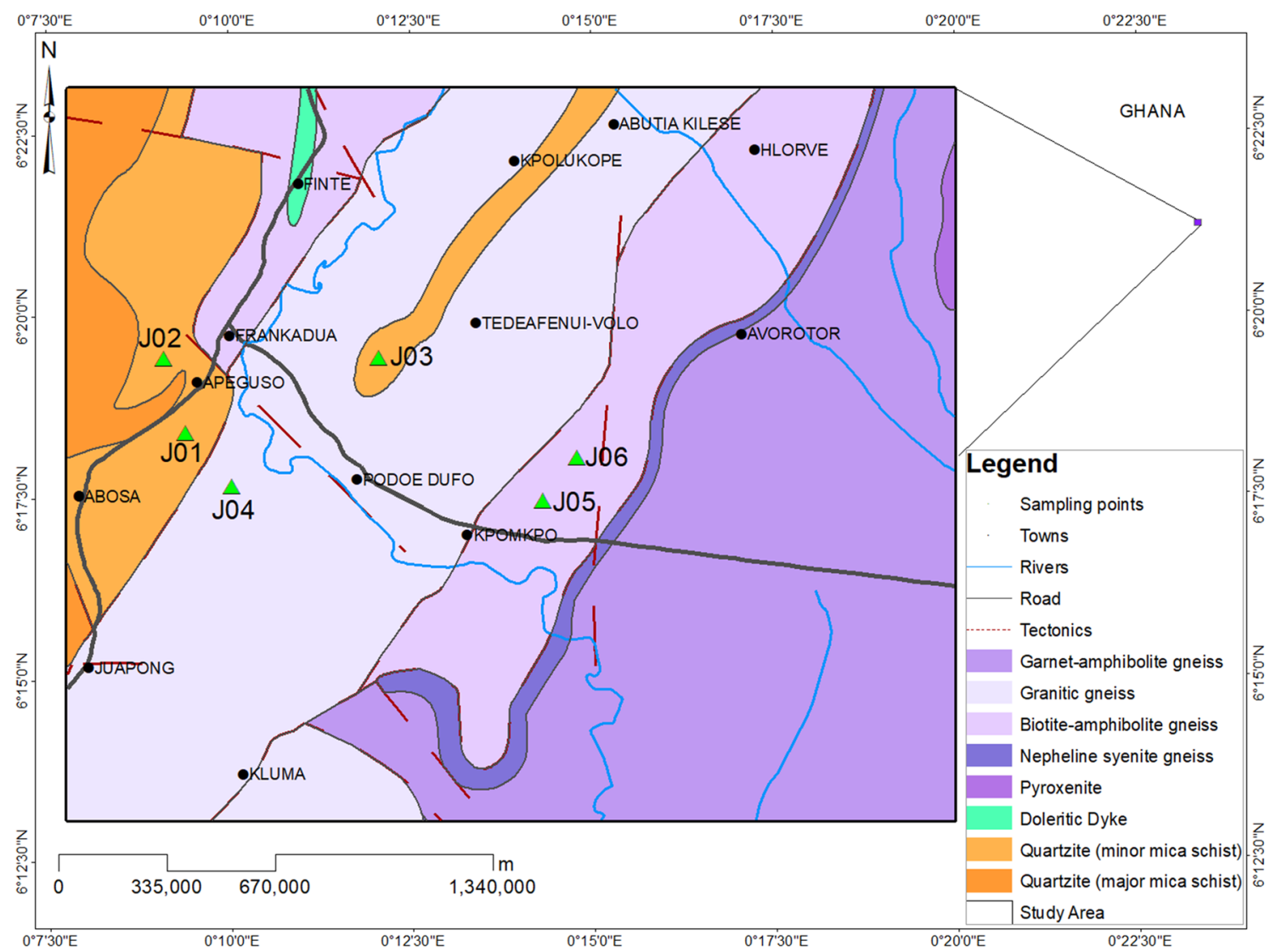

Fig. 2 Geological map of the study area showing the distribution of sampling locations in the study area [34]
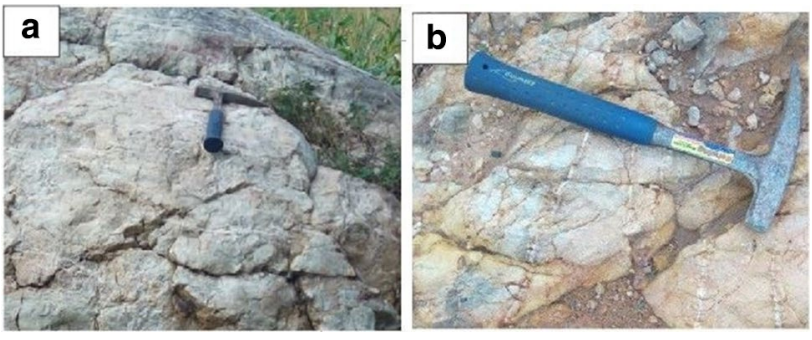

Fig. 3 Field photographs of quartzites in the study area showing; a massive quartzite, $\mathbf{b}$ quartz veins healing fractures in quartzite
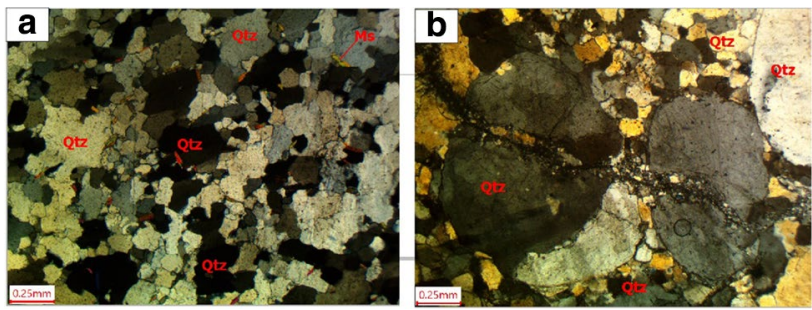

Fig. 4 Photomicrograph of quartzites showing a sutured and coalesced quartz grains, b quartz grains with a porphyroblastic texture
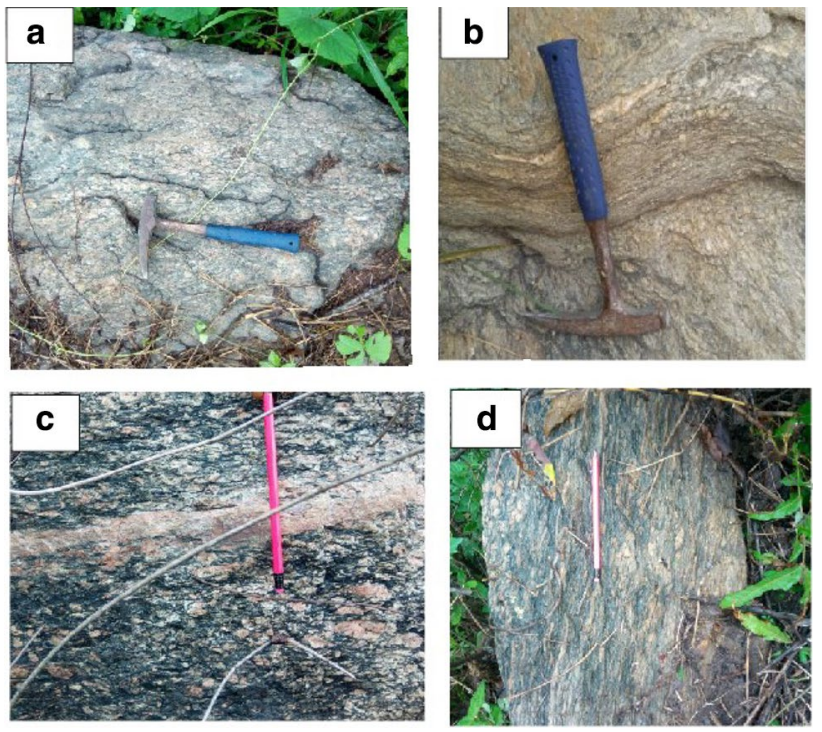

Fig. 5 Field photograph of gneisses showing a weathered granitic augen gneiss, $\mathbf{b}$ recrystalline grains in biotite gneiss, $\mathbf{c}$ granitic vein in augen gneiss, $\mathbf{d}$ gneissic bands in the gneiss rock

\section{SN Applied Sciences}


biotite gneiss (Fig. 5b) at Afode is fresh and unweathered as compared to the granitic augen gneiss at other parts of the study area. The biotite gneisses observed at Podoe and Afode are relatively light to white with some dark portions. These gneisses have recrystalline grains with similar bands of segregated minerals. The gneisses have minerals of powdery pinkish feldspar, quartz, flaky biotite and hornblende. The gneisses have a general orientation in the NE-SW direction. Microscopically, the granitic augen gneiss is medium to coarse grained with relatively protomylonitic textures with augens, which are dominantly large fragmented quartz grains due to deformation and are mantled by biotite (Fig. 6a). The proto-mylonitic textures have a strongly layered appearance due to variations in the amount of deformation and variations in compositions. The hornblende which is weakly deformed is surrounded by strongly deformed biotite. The pulverisation of grains due to ductile deformation leaves remnants of porphyroclasts from the protolith in the augen gneiss. The biotite gneiss is medium grained with plagioclase that has been deformed (Fig. $6 \mathrm{~b}$ ). The biotite has been aligned according to the foliation planes in the gneiss (Fig. $6 c, d$ ). The quartz grains in the biotite gneiss exhibit undulose extinction. It can be inferred that the deformed biotite granite resulted in a protolith of the augen gneiss. The deformation style of the feldspar and quartz also indicates metamorphism which did not exceed the middle greenschist facies.

\subsection{Structures analyses}

Geological field observation and systematic measurement of structural features were made to assist interpretation of

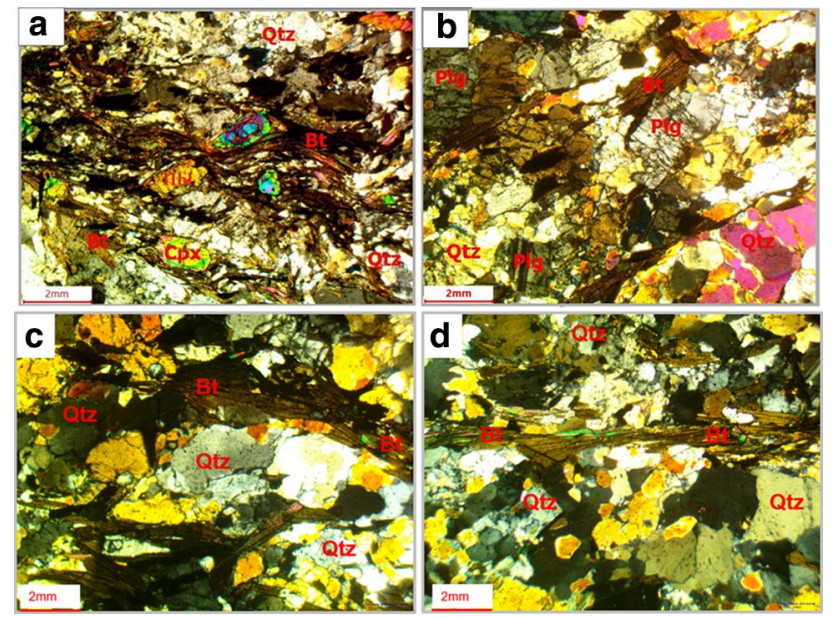

Fig. 6 Photomicrograph of the gneisses showing a proto-mylonitic texture in granitic augen gneiss, b biotite gneiss with deformed plagioclase mineral grains, $\mathbf{c}, \mathbf{d}$ biotite mineral alignment in biotite gneiss activities that occurred before, during and after the formation of outcrops encountered in the area of study. Some structures observed in the rocks exposed in the study area include veins, foliations, joints and lineations.

Foliations were observed in the granitic gneiss, biotite gneiss and the quartzites encountered in the field (Fig. 7a, b). The gneisses have very thin and average foliation thickness of about 1-9 $\mathrm{mm}$. The foliated quartzites have an average thickness of $2-15 \mathrm{~cm}$. The presence of foliations may be as a result of deviatoric pressure exerted unequally on the rock in different direction causing alignment of minerals in the rocks. They have a general northeast-south-west direction with strike values between $038^{\circ}$ and $280^{\circ}$ as shown in the rose diagram in Fig. 7c. The foliations have varying dips with steep south-westerly dips of about $85^{\circ}$ (Fig. 7 d).

Most of the joints observed in the study area are restricted to mainly the quartzites. The joints observed in the quartzites were mainly haphazard due to the varying degrees of deformational stress that is both concordant and discordant to the foliation planes in the quartzites. The rocks have fractures being healed by quartz veins (Fig. 8a). The joints were also parallel to each other (Fig. 8b). The joints resulted from stresses exerted on the rocks in several directions caused by brittle deformation at shallow crustal levels. The joints break the continuity in the rocks. Various attitudinal measurements of strike, dip and dip directions were

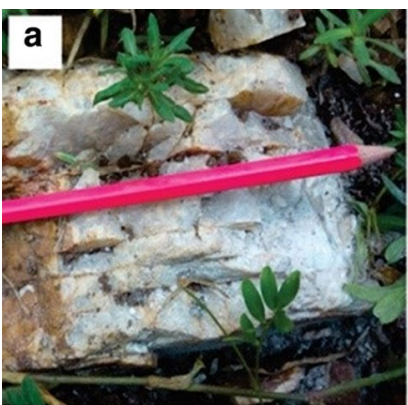

C

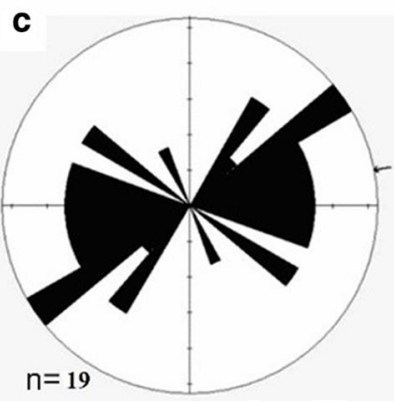

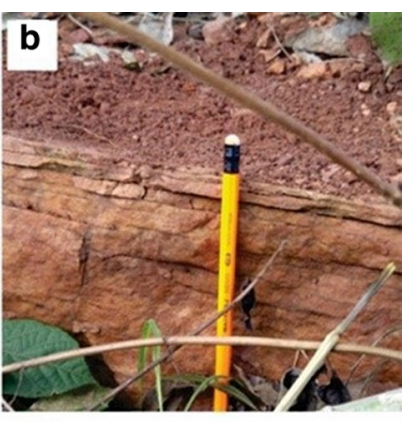

d

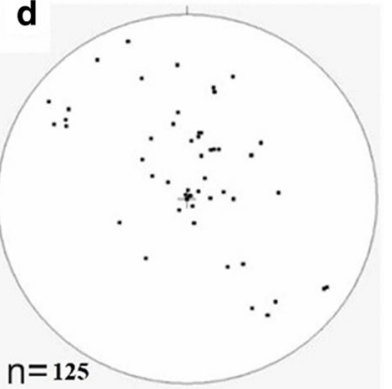

Fig. 7 Field photographs of foliations in quartzites and their stereoplots showing $\mathbf{a}$, $\mathbf{b}$ foliation in quartzite, $\mathbf{c}$ rose diagram of foliation planes indicating general directional trend of the foliations and $\mathbf{d}$ plot of poles to foliation planes 

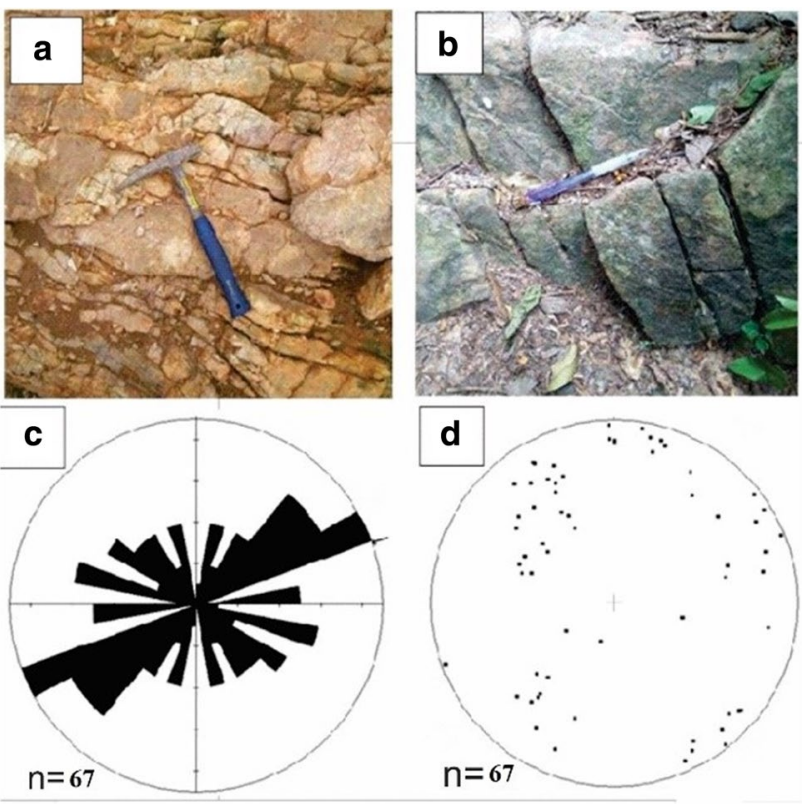

Fig. 8 Field photographs joints and their stereoplots showing a image of haphazard joints in the jointed quartzite, $\mathbf{b}$ image of discordant joint, c rose diagram of joint planes indicating general directional trend of the joints, $\mathbf{d}$ plot of poles to joint plane

recorded for the joints according to their orientation. The principal dips of the joints are in the northeast-south-west (Fig. 8c) direction with moderately steep dips of about $70^{\circ}-66^{\circ}$ (Fig. $8 \mathrm{~d}$ ). The veins heal and seal the fractures in the quartzites and gneisses in the study area. Brittle deformation at shallow crustal levels caused the fractures. The quartz veins in some areas are granitic such as in the augen gneiss (Fig. 9a). These fractures are filled with quartz veins as a result of differential metamorphism. The quartz veins are encountered in almost all the rocks in the study area (Fig. 9a-d). The quartz veins crosscut each other in some areas forming a stock work of veins as well (Fig. 9d). The quartz veins have varying thickness of about $1 \mathrm{~cm}$ to about $2 \mathrm{~cm}$. The quartz veins are evidence of metamorphism which form as a result of partial melting, remobilisation of low-temperature minerals such as quartz along fractures and recrystallisation of these quartz minerals when exposed to higher temperatures and pressures.

Lineations found in the gneisses have head and tail structures rich in stretched feldspar minerals (Fig. 10a). The lineations are constructed which resulted from the intersection of primary shear stresses with secondary shear stresses caused by tectonics and deformation. The minerals within the lineations further define the alignment of the minerals within the rock especially the granitic gneiss (Fig. 10b). The lineations have a general intermediate to steep dips with the north-easterly lineations having a
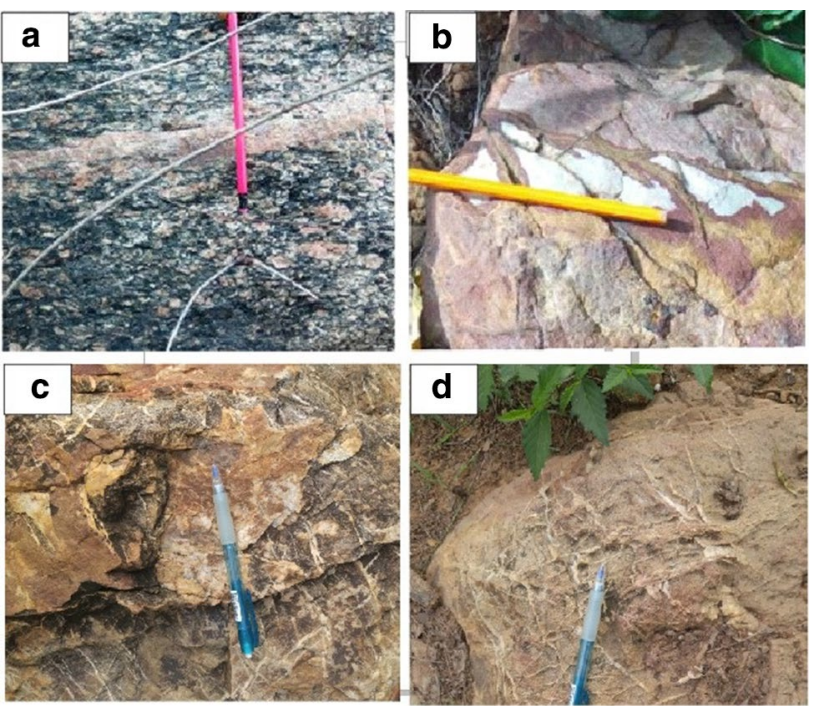

Fig. 9 Field photograph of veins showing a granitic vein in augen gneiss, b quartz vein in quartzite, c rose diagram projection for quartz veins, $\mathbf{d}$ stereographic poles plot for the veins showing the dip and the dip direction

steep dip of about $50^{\circ}$. The linear structures have an orientation in the north-east-south-west direction (Fig. 10c). The south-westerly lineations have shallow dips closer to the circumference (Fig. 10d).
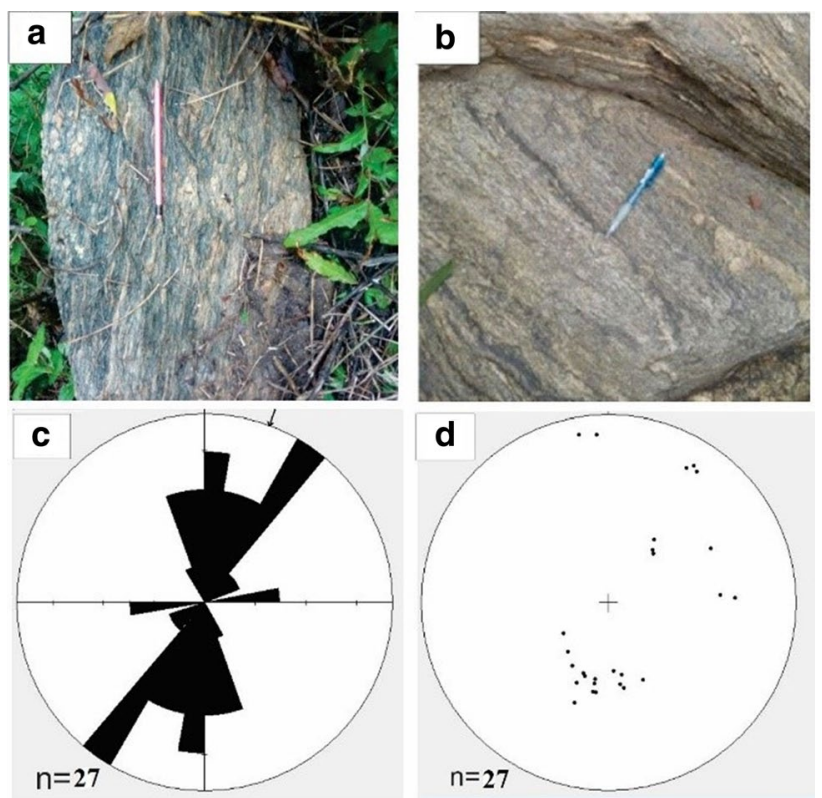

Fig. 10 Field photograph of gneisses and their stereoplots showing a lineations in augen gneiss, $\mathbf{b}$ lineations in biotite gneiss, $\mathbf{c}$ rose diagram projection for the lineations, $\mathbf{d}$ stereographic poles plot for the lineations showing the trend and plunge 


\subsection{Geochemistry of trace elements}

The three quartzite rock samples contain high silica $\left(\mathrm{SiO}_{2}\right)$ content (between 96.56 and $98.29 \mathrm{wt} \%$ ), $\mathrm{Al}_{2} \mathrm{O}_{3}$ of $0.11-0.66 \mathrm{wt} \%, \mathrm{Na}_{2} \mathrm{O}$ of $0.01-0.03$ wt $\%, \mathrm{MgO}$ of $0.01-0.03 w t \%, \mathrm{Fe}_{2} \mathrm{O}_{3}$ of $0.23-2.16 \mathrm{wt} \%, \mathrm{CaO}$ of $0.01-0.02$ wt $\%$ (Table 1). The quartzites consist of high amounts of silica content mainly rich in quartz. The quartzite samples were traced back to their sedimentary sandstone sources to be able to use the plots for their interpretation. The major elements can be used to determine the tectonic settings, classify and deduce the extent of chemical weathering in the source area of the metamorphic rocks.

A plot proposed by Herron [15] was used for classification of the quartzite. Logarithmic plots of $\mathrm{SiO}_{2} / \mathrm{Al}_{2} \mathrm{O}_{3}$ against $\mathrm{Fe}_{2} \mathrm{O}_{3} / \mathrm{K}_{2} \mathrm{O}$ are shown in Fig. 11 a. The quartzites are classified as quartz arenites. A plot proposed by Roser and Korsch [16] was used to determine the tectonic setting of the quartzites. $\mathrm{K}_{2} \mathrm{O} / \mathrm{Na}_{2} \mathrm{O}$ was plotted against $\mathrm{SiO}_{2}$ as shown in Fig. $11 \mathrm{~b}$. The quartzites plot in the passive margin field. The normalised average crust patterns in Fig. 12a show similar trends and enrichment in certain elements with depletion in same elements. The trace elements have a general poor enrichment in the quartzites as compared to that of the average crust. There is a steep spike in the elements: $\mathrm{Rb}(0.02-008 \mathrm{ppm}), \mathrm{U}(0.2-0.003 \mathrm{ppm})$, Th $(0.25-0.021 \mathrm{ppm}), \mathrm{K}(0.019-0.08 \mathrm{ppm}), \mathrm{Nb}$ (0.02-0.05 ppm), with slight depletions in $\mathrm{Sr}(0.002 \mathrm{ppm})$ and $\mathrm{Sm}(0.008 \mathrm{ppm})$ in the muscovite-rich quartzite. Comparison of the quartzite to the upper continental crust as shown in Fig. 12b shows that the elemental concentrations of the trace elements are generally below the upper continental crust (UCC). The quartzites show a parallel signature with some few depletions and enrichment in some elements. The elements $\mathrm{Cs}, \mathrm{Sr}, \mathrm{P}, \mathrm{Ti}, \mathrm{Nb}$ and $\mathrm{Ta}$ have negative anomalies, while $\mathrm{Hf}, \mathrm{Zr}, \mathrm{La}, \mathrm{Ce}, \mathrm{Nd}$ and $\mathrm{Ba}$ elements show positive anomalies in all three rock samples. Roser and Korsch [17] proposed a plot based on major element concentration to differentiate the provenance of sediments (Fig. 13a). Four categories of provenance are used, namely felsic igneous, intermediate igneous, mafic igneous and quartzose sedimentary. The rock samples plot in the quartzose sedimentary field which implies that the source of the quartzites was derived primarily from felsic continental sources which are similar to the rocks from the passive margin provenance proposed earlier by Osae et al. [18]. Dickinson [19] proposed that the main sources of craton-derived quartzose sands are from granitic and gneissic exposures in low-lying areas. This is aided by the recycling of surrounding flat-lying sediments. Due to the absence or little tectonic activity associated with the passive margin settings, it is inferred that the sediments
Table 1 Distribution of major (wt\%) and trace elements (ppm) of the metamorphic rocks of sedimentary origin

\begin{tabular}{|c|c|c|c|}
\hline Samples (wt\%) & Quartzite (J01) & Quartzite (J02) & Quartzite (J03) \\
\hline \multicolumn{4}{|l|}{$W t \%$} \\
\hline $\mathrm{SiO}_{2}$ & 98.25 & 96.56 & 98.29 \\
\hline $\mathrm{Al}_{2} \mathrm{O}_{3}$ & 0.66 & 0.37 & 0.11 \\
\hline $\mathrm{BaO}$ & 0.02 & 0.02 & 0.01 \\
\hline $\mathrm{CaO}$ & 0.02 & 0.02 & 0.01 \\
\hline $\mathrm{Fe}_{2} \mathrm{O}_{3}$ & 0.23 & 2.16 & 0.29 \\
\hline $\mathrm{K}_{2} \mathrm{O}$ & 0.17 & 0.13 & 0.04 \\
\hline $\mathrm{MgO}$ & 0.07 & 0.06 & 0.01 \\
\hline $\mathrm{MnO}$ & 0.01 & 0.12 & 0.01 \\
\hline $\mathrm{Na}_{2} \mathrm{O}$ & 0.03 & 0.02 & 0.01 \\
\hline $\mathrm{P}_{2} \mathrm{O}_{5}$ & 0.01 & 0.02 & 0.01 \\
\hline $\mathrm{TiO}_{2}$ & 0.04 & 0.03 & 0.01 \\
\hline LOI 1000 & 0.22 & 0.5 & 0.16 \\
\hline Total & 99.73 & 100.05 & 98.96 \\
\hline $\mathrm{CaO} * \mathrm{Na}_{2} \mathrm{O}$ & 0.0006 & 0.0004 & 0.0001 \\
\hline $\mathrm{Al}_{2} \mathrm{O}_{3}$ & 0.66 & 0.37 & 0.11 \\
\hline $\mathrm{K}_{2} \mathrm{O} / \mathrm{Na}_{2} \mathrm{O}$ & 5.67 & 6.5 & 4 \\
\hline $\log \left(\mathrm{SiO}_{2} / \mathrm{Al}_{2} \mathrm{O}_{3}\right)$ & 2.17 & 2.42 & 2.95 \\
\hline $\log \mathrm{Fe}_{2} \mathrm{O}_{3} / \mathrm{K}_{2} \mathrm{O}$ & 0.13 & 1.22 & 0.86 \\
\hline $\begin{array}{l}\text { Discriminant } \\
\text { function } 1\end{array}$ & -8.87 & -7.5 & -8.87 \\
\hline $\begin{array}{l}\text { Discriminant } \\
\text { function } 2\end{array}$ & 4.46 & 4.18 & 3.55 \\
\hline $\mathrm{ClA}$ & 75 & 68.52 & 64.71 \\
\hline \multicolumn{4}{|l|}{ ppm } \\
\hline $\mathrm{Ba}$ & 37.9 & 47.5 & 10 \\
\hline $\mathrm{Ce}$ & 6.9 & 33.5 & 1.1 \\
\hline $\mathrm{Cr}$ & 10 & 50 & 30 \\
\hline Cs & 0.13 & 0.14 & 0.05 \\
\hline Dy & 0.29 & 0.64 & 0.05 \\
\hline $\mathrm{Er}$ & 0.27 & 0.32 & 0.03 \\
\hline $\mathrm{Eu}$ & 0.05 & 0.33 & 0.03 \\
\hline $\mathrm{SrO}$ & 0.01 & 0.01 & 0.01 \\
\hline $\mathrm{Cr}_{2} \mathrm{O}_{3}$ & 0.01 & 0.02 & 0.02 \\
\hline $\mathrm{SO}_{3}$ & 0.01 & 0.01 & 0.01 \\
\hline $\mathrm{Ga}$ & 0.8 & 0.6 & 0.2 \\
\hline $\mathrm{Gd}$ & 0.3 & 1.13 & 0.05 \\
\hline $\mathrm{Hf}$ & 0.9 & 0.9 & 0.2 \\
\hline Ho & 0.06 & 0.1 & 0.01 \\
\hline La & 4.7 & 13.7 & 0.8 \\
\hline Lu & 0.02 & 0.04 & 0.01 \\
\hline $\mathrm{Nb}$ & 0.6 & 0.4 & 0.2 \\
\hline $\mathrm{Nd}$ & 2.9 & 11.9 & 0.6 \\
\hline $\operatorname{Pr}$ & 0.84 & 3.04 & 0.12 \\
\hline $\mathrm{Rb}$ & 4.6 & 4.4 & 1.3 \\
\hline Sm & 0.41 & 1.73 & 0.03 \\
\hline Sn & 1 & 1 & 1 \\
\hline $\mathrm{Sr}$ & 5.3 & 10.1 & 1.2 \\
\hline Ta & 0.1 & 0.1 & 0.1 \\
\hline
\end{tabular}


Table 1 (continued)

\begin{tabular}{llll}
\hline Samples (wt\%) & Quartzite (J01) & Quartzite (J02) & Quartzite (J03) \\
\hline Tb & 0.04 & 0.12 & 0.01 \\
Th & 1.04 & 1.29 & 0.15 \\
Tm & 0.03 & 0.04 & 0.01 \\
U & 0.26 & 0.31 & 0.05 \\
V & 5 & 5 & 5 \\
W & 1 & 1 & 1 \\
Y & 1.3 & 2.9 & 0.5 \\
Yb & 0.1 & 0.23 & 0.03 \\
Zr & 35 & 28 & 6 \\
\hline
\end{tabular}

had undergone long periods of transportation, chemical weathering and abrasion which lead to mineral maturation. The high content of the quartz in the quartzite is likely to correspond to the fact that the protolith was derived from granitic and gneissic sources [20]. To determine the extent of weathering of the metamorphic rocks of sedimentary origin, the A-CN-K plot is used (Fig. 13b). This is used to determine the degree to which the rocks have been weathered before being transported to their depositional environments. The $\mathrm{A}-\mathrm{CN}-\mathrm{K}$ plots $\mathrm{Al}_{2} \mathrm{O}_{3}, \mathrm{~K}_{2} \mathrm{O}$ and $\mathrm{CaO}+\mathrm{Na}_{2} \mathrm{O}$ against the chemical index of alteration (CIA) values. The $\mathrm{CIA}$ values determine the extent of chemical weathering of rocks. The quartzites plotted in the muscovite-illite range of the $\mathrm{A}-\mathrm{CN}-\mathrm{K}$ diagram. The quartzites have $\mathrm{CIA}$ values of $75,68.52$ and 64.71 . Values ranging from 0 to $49 \%$ indicate relatively low to very low weathering conditions, whereas values ranging from about $50-84 \%$ and values greater than or equal to $85 \%$, respectively, indicate an intermediate to intense weathering. The CIA values obtained for the quartzites suggest that the source region was subjected to intermediate tropical weathering owing to the humid climatic conditions in the area at the time of disintegration of the source rocks [21]. The gneissic rocks are also characterised by moderate to high silica $\left(\mathrm{SiO}_{2}\right)$ content ranging from 66.39 to $73.42 \mathrm{wt} \%, \mathrm{Al}_{2} \mathrm{O}_{3}$ of $13.33 \mathrm{wt} \%$ and $15.43 \mathrm{wt} \% \mathrm{Al}_{2} \mathrm{O}_{3}, \mathrm{TiO}_{2}$ of $0.3-0.63 \mathrm{wt} \%$, $\mathrm{MgO}$ of $0.62-1.36 \mathrm{wt} \%, \mathrm{CaO}$ of $1.52-3.02 \mathrm{wt} \%, \mathrm{~K}_{2} \mathrm{O}$ of 2.67-4.33 wt\%, $\mathrm{Na}_{2} \mathrm{O}$ of $3.08-4.45 \mathrm{wt} \%$ and $\mathrm{Fe}_{2} \mathrm{O}_{3}$ of 2.19-4.45 wt\% (Table 2). The gneissic samples were plotted separately based on their elemental data. Various plots for the rock samples will help determine the evolution and source of the magma and the tectonic environment of their emplacement as well as their provenance. Table 2 shows the distribution of the trace and major elements for the gneissic rocks.

A plot after Werner [22] plots $\mathrm{P}_{2} \mathrm{O}_{5} / \mathrm{TiO}_{2}$ against $\mathrm{MgO} /$ $\mathrm{CaO}$, while a plot after Mackenzie and Garrels [23] also plots $\mathrm{Na}_{2} \mathrm{O} / \mathrm{Al}_{2} \mathrm{O}_{3}$ against $\mathrm{K}_{2} \mathrm{O} / \mathrm{Al}_{2} \mathrm{O}_{3}$ to determine the protolith of the gneisses (Fig. 14a, b). The gneissic rock samples plotted within the igneous field of both plots used by these authors. The gneisses are therefore concluded to be orthogneisses of igneous origin and not of sedimentary origin. The high ratio of alkali elements, phosphorous and titanium oxides suggests a crystalline phase for forming the rocks; otherwise, a low concentration of alkali elements would have suggested a high degree of weathering possibly from sedimentary origin. The use of major elements as well as major oxides is necessary for determining the source of melts that formed a rock [24]. It is also used for studying alteration, petrogenesis and tectonic associations of mafic or felsic volcanic rocks [25]. The AFM geochemical diagram is used to ascertain the type of magma that evolved to deposit the metamorphic rocks as to whether it was calc-alkaline or tholeiitic in nature with the aid of the major elements present in the rock (Fig. 15a). The rocks plotted in the calc-alkaline
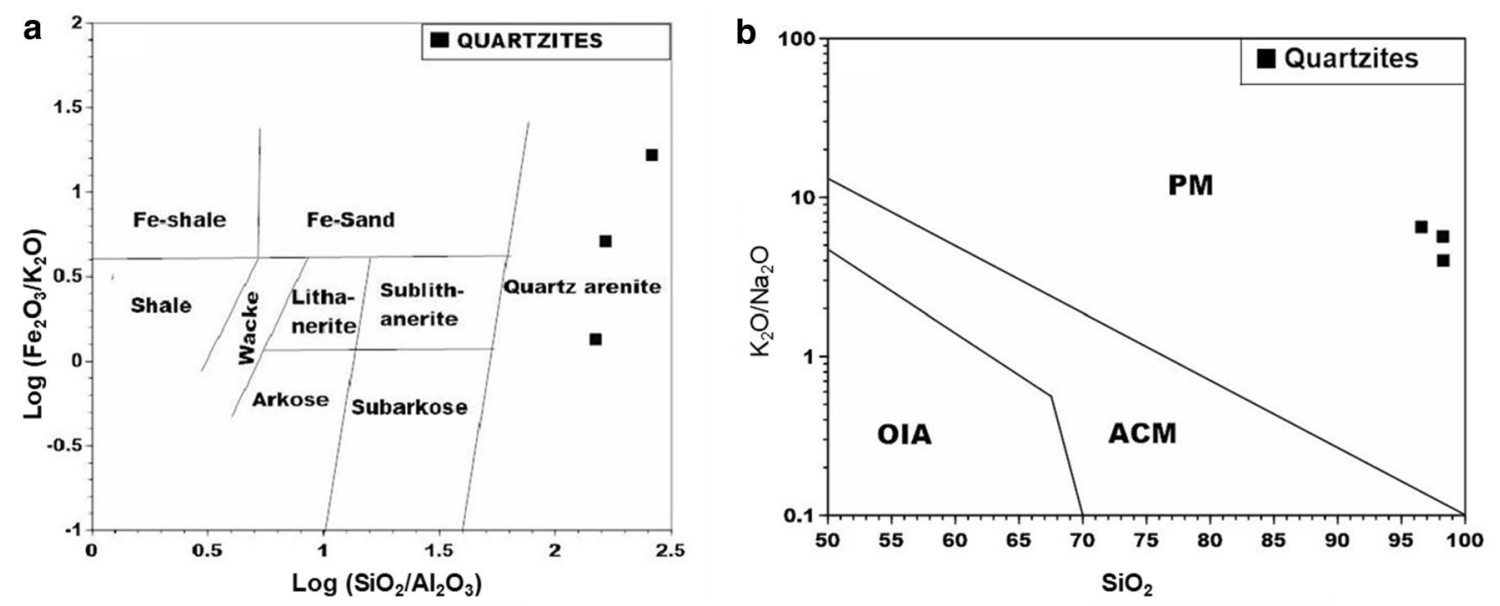

Fig. 11 Geochemical plots for the classification of quartzites showing a classification of quartzites with log $\mathrm{Fe}_{2} \mathrm{O}_{3} / \mathrm{K}_{2} \mathrm{O}$ against $\mathrm{SiO} \mathrm{O}_{2} / \mathrm{Al}_{2} \mathrm{O}_{3}$, after Herron [15], b tectonic setting diagram of quartzites based on major elements using $\mathrm{K}_{2} \mathrm{O} / \mathrm{Na}_{2} \mathrm{O}$ versus $\mathrm{SiO}_{2}$, after Roser and Korsch [16] 

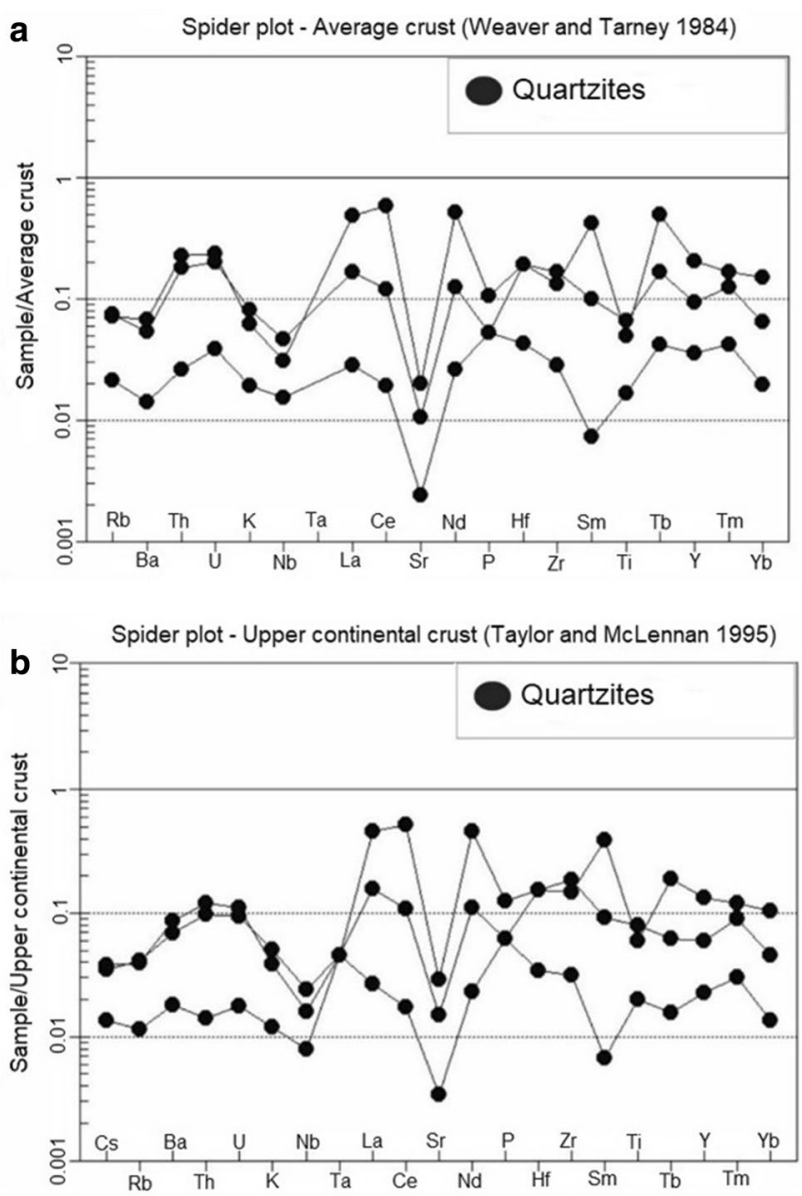

Fig. 12 Spider plots for the quartzites showing a REE plot of the quartzite samples normalised against the upper continental crust after Taylor and McLennan [35], b REE plots of the quartzites normalised against the average crust, after Weaver and Tarney [36] field which suggests that magma is evolved. This suggests that the gneisses contain more alkali elements. Cox et al. [26] devised a plot for classifying plutonic igneous rocks. On the TAS plot, the gneisses plot within the granodiorite and granite fields (Fig. 15b). This is contrary to the geochemistry of the AFM plot, likely due to major element mobility owing to weak metamorphism. The granitic augen gneiss and biotite gneisses from Afode and Podoe are granites and calc-alkaline in nature. The binary geotectonic discriminant plot (Fig. 16) after Pearce et al. [27] plots $\mathrm{Rb}$ against $\mathrm{Y}+\mathrm{Nb}, \mathrm{Nb}$ against $\mathrm{Y}, \mathrm{Rb}$ against $\mathrm{Ta}+\mathrm{Yb}$ and $\mathrm{Ta}$ against $Y b$. These plots help to determine the environment in which the precursors of the gneisses were emplaced. The data from this study show that the igneous precursors were emplaced in a volcanic arc terrain making them volcanic arc granites. From the chondrite-normalised plot in Fig. 17a after Boynton [28], the three rock types are generally enriched in rare earth elements (REE) as compared to chondrite. The patterns from the chondrite-normalised plot (Fig. 17a) after Boynton [28] for the rock samples from this study area shows a general enrichment in trace elements as that of the REE chondrite. The light rare earth elements (LREE) compared to the heavy rare earth elements (HREE) are enriched with a nearly flat slight positive europium anomaly in the biotite gneisses and a negative anomaly in the granitic augen gneiss. The europium anomaly has a slight negative anomaly of about $2 \mathrm{ppm}$ in the granitic augen gneiss and about 10-11 ppm in the biotite gneisses. The slight negative europium anomaly indicates that the magma which gave rise to this granite suffered minor plagioclase fractionation [29]. Compared the rock samples with the primitive mantle after McDonough and Sun [30], there was a general LREE enrichment with low enrichment in HREE (Fig. 17b). The samples show a distinct

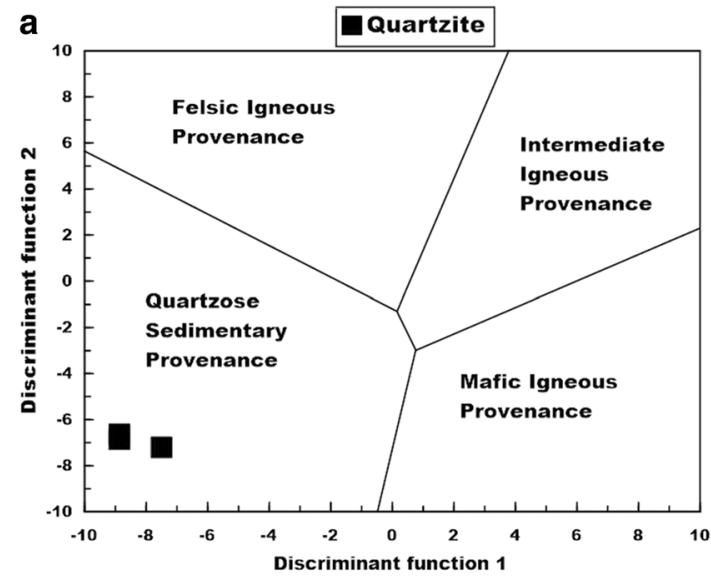

Fig. 13 Classification of quartzites showing a discriminant function diagram for the provenance of the quartzites, after Roser and Korsch [17], b chemical index of alteration $\mathrm{ClA}=100 \times\left[\mathrm{Al}_{2} \mathrm{O}_{3} /\right.$ b



$\left.\left(\mathrm{Al}_{2} \mathrm{O}_{3}+\mathrm{CaO}+\mathrm{Na}_{2} \mathrm{O}+\mathrm{K}_{2} \mathrm{O}\right)\right]$ and $\mathrm{A}-\mathrm{CN}-\mathrm{K}$ ternary diagram of molecular proportions of $\mathrm{Al}_{2} \mathrm{O}_{3}-\left(\mathrm{CaO}+\mathrm{Na}_{2} \mathrm{O}\right) \mathrm{K}_{2} \mathrm{O}$ in the quartzitic rocks, after Shao and Yang [37] 
Table 2 Distribution of whole-rock major (wt\%) and trace (ppm) elements in gneissic samples

\begin{tabular}{|c|c|c|c|}
\hline Samples & $\begin{array}{l}\text { Granitic augen } \\
\text { gneiss (JEM 01) }\end{array}$ & $\begin{array}{l}\text { Biotite gneiss } \\
\text { (JEM 02) }\end{array}$ & $\begin{array}{l}\text { Biotite } \\
\text { gneiss } \\
\text { (JEM 06) }\end{array}$ \\
\hline \multicolumn{4}{|l|}{$W t \%$} \\
\hline $\mathrm{SiO}_{2}$ & 73.42 & 69.7 & 66.39 \\
\hline $\mathrm{Al}_{2} \mathrm{O}_{3}$ & 13.33 & 14.21 & 15.43 \\
\hline $\mathrm{BaO}$ & 0.16 & 0.09 & 0.09 \\
\hline $\mathrm{CaO}$ & 1.71 & 1.52 & 3.02 \\
\hline $\mathrm{Fe}_{2} \mathrm{O} 3$ & 2.19 & 3.15 & 4.45 \\
\hline $\mathrm{K}_{2} \mathrm{O}$ & 4.33 & 3.58 & 2.67 \\
\hline $\mathrm{MgO}$ & 0.62 & 1.09 & 1.36 \\
\hline $\mathrm{MnO}$ & 0.03 & 0.03 & 0.06 \\
\hline $\mathrm{Na}_{2} \mathrm{O}$ & 3.08 & 4.12 & 4.45 \\
\hline $\mathrm{P}_{2} \mathrm{O}_{5}$ & 0.11 & 0.17 & 0.26 \\
\hline $\mathrm{TiO}_{2}$ & 0.3 & 0.44 & 0.63 \\
\hline LOI 1000 & 0.55 & 0.52 & 0.62 \\
\hline Total & 99.94 & 98.72 & 99.56 \\
\hline \multicolumn{4}{|l|}{ ppm } \\
\hline $\mathrm{Ba}$ & 1300 & 794 & 712 \\
\hline $\mathrm{SO}_{3}$ & 0.01 & 0.01 & 0.02 \\
\hline $\mathrm{SrO}$ & 0.05 & 0.03 & 0.05 \\
\hline $\mathrm{Cr}_{2} \mathrm{O}_{3}$ & 0.01 & 0.01 & 0.01 \\
\hline $\mathrm{Ce}$ & 39.1 & 73.7 & 63.7 \\
\hline $\mathrm{Cr}$ & 20 & 20 & 20 \\
\hline Cs & 0.17 & 0.62 & 1.23 \\
\hline Dy & 0.66 & 2.37 & 2.63 \\
\hline $\mathrm{Er}$ & 0.35 & 0.81 & 1.29 \\
\hline $\mathrm{Eu}$ & 0.71 & 1.2 & 1.07 \\
\hline $\mathrm{Ga}$ & 16.6 & 20.2 & 23.5 \\
\hline $\mathrm{Gd}$ & 1.19 & 3.95 & 3.35 \\
\hline $\mathrm{Hf}$ & 5.1 & 7.2 & 8.1 \\
\hline $\mathrm{Ho}$ & 0.12 & 0.4 & 0.43 \\
\hline $\mathrm{La}$ & 19.5 & 36.4 & 32 \\
\hline $\mathrm{Lu}$ & 0.04 & 0.09 & 0.21 \\
\hline $\mathrm{Nb}$ & 4.2 & 8.6 & 11.9 \\
\hline $\mathrm{Nd}$ & 15.6 & 37.7 & 26.7 \\
\hline $\operatorname{Pr}$ & 4.46 & 9.43 & 7.27 \\
\hline $\mathrm{Rb}$ & 95.3 & 116 & 97.8 \\
\hline $\mathrm{Sm}$ & 2.47 & 6.48 & 4.7 \\
\hline Sn & 1 & 2 & 3 \\
\hline $\mathrm{Sr}$ & 479 & 298 & 449 \\
\hline $\mathrm{Ta}$ & 0.1 & 0.7 & 0.6 \\
\hline $\mathrm{Tb}$ & 0.2 & 0.52 & 0.46 \\
\hline Th & 3.46 & 13.75 & 11.5 \\
\hline $\mathrm{Tm}$ & 0.06 & 0.14 & 0.21 \\
\hline$U$ & 0.5 & 1.06 & 4.75 \\
\hline $\mathrm{V}$ & 26 & 40 & 75 \\
\hline W & 1 & 1 & 1 \\
\hline$Y$ & 3.8 & 10.8 & 11 \\
\hline $\mathrm{Yb}$ & 0.24 & 0.79 & 1.22 \\
\hline
\end{tabular}

Table 2 (continued)

\begin{tabular}{lll}
\hline $\mathrm{Zr}$ & 269 & 318 \\
\hline
\end{tabular}

trough in $\mathrm{Ta}, \mathrm{Cs}$ and $\mathrm{P}$ of about 2-8 ppm for the augen gneiss as compared to the biotite gneisses with a general enrichment in $\mathrm{Ba}, \mathrm{Zr}, \mathrm{Rb}, \mathrm{U}$ and Th with above $10 \mathrm{ppm}$. The granitic augen gneiss shows a great enrichment in LREE of $\mathrm{Rb}, \mathrm{Ba}$ and Th over the biotite gneisses. Ti depletion, europium enrichment and a depletion in $\mathrm{Nb}$, Ta and $\mathrm{P}$ are a signature of volcanic arc terrain rocks as proposed by Pearce et al. [27].

\subsection{Evidence and interpretation of the neoproterozoic Pan-African orogenic event}

The rocks found in the study area can be broadly divided into two groups, namely gneisses and quartzites. From the field observation, the gneiss which forms part of the Dahomeyan basement can be put at the bottom of the stratigraphic sequence. This basement might have undergone an initial metamorphism which converted the quartzo-feldspathic (granitic) protolith into gneissic rocks. A probable tectonic activity might have led to subsidence creating basins at deeper crustal level for the deposition of arenaceous sediments which might have been eroded from granitic or gneissic basement. The basement gneissic rock together with the deposited arenaceous sediments indicates most probably middle greenschist facies metamorphism during the Pan-African Orogeny. During this period, the lithospheric collision released great temperature and pressure bringing about the regional dynamothermal metamorphism, converting the arenaceous sediments in quartzites and overprinting the gneissic basement. Based on field relations, it can be inferred that the quartzites were juxtaposed to the gneisses with the gneisses occupying the central portions of the study area. It is further buttressed with the fact that, on the field, the gneisses occupied majority of the lowlands as compared to the quartzites on higher elevations. In addition, the gneisses which have igneous precursors, believed to belong to the Dahomeyide, resulted from the Eburnean tectonothermal event. The protolith of the gneissic rocks was inferred to have formed from fractionated magma emplaced at different periods of time. Majority of the gneisses observed in the field were sheared and foliated. This is evident that the gneissic precursors were emplaced first and were acted by north-east-south-west shear stresses. Also, shallow crustal brittle deformation probably caused the formation of joints within the whole study area. The primary cohesive cataclastic feature manifested by the 

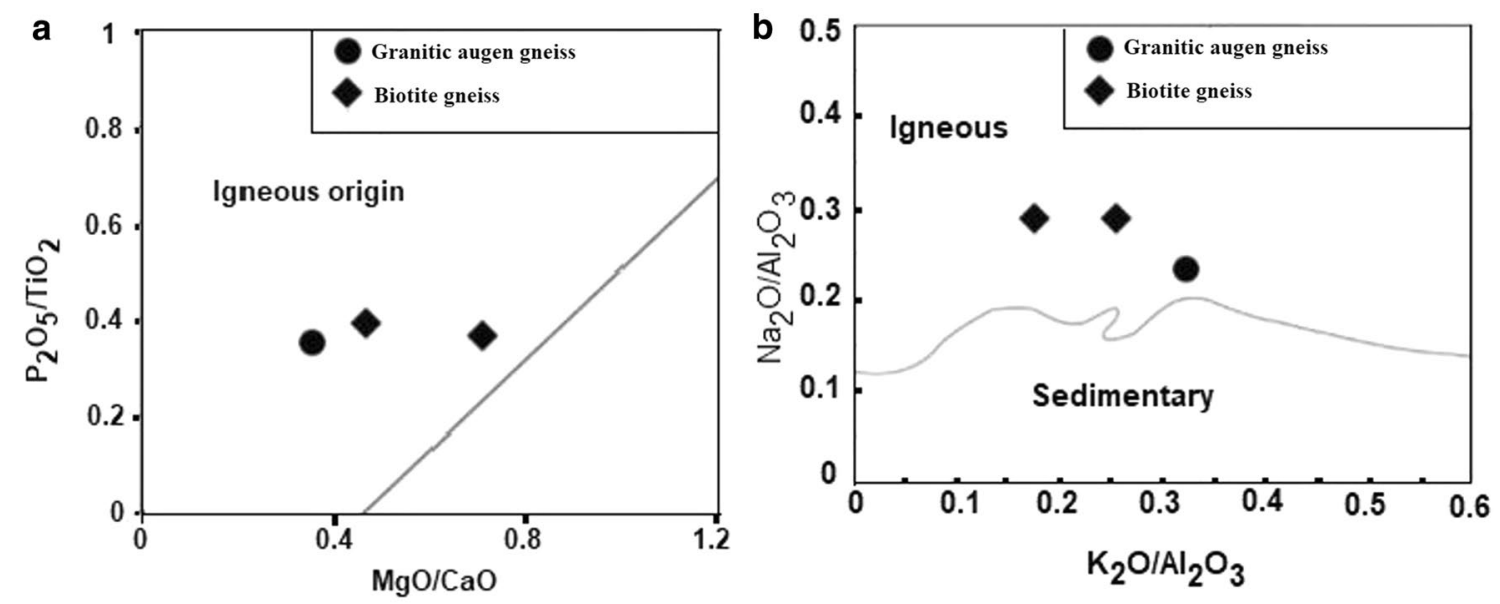

Fig. 14 Geochemical plots for the gneissic rocks showing its protolith; a a binary plot of $\mathrm{P}_{2} \mathrm{O}_{5} / \mathrm{TiO}_{2}$ versus $\mathrm{MgO} / \mathrm{CaO}$, after Werner [22]; $\mathbf{b}$ a binary plot of $\mathrm{Na}_{2} \mathrm{O} / \mathrm{Al}_{2} \mathrm{O}_{3}$ against $\mathrm{K}_{2} \mathrm{O} / \mathrm{Al}_{2} \mathrm{O}_{3}$, after Mackenzie and Garrels [23]

a

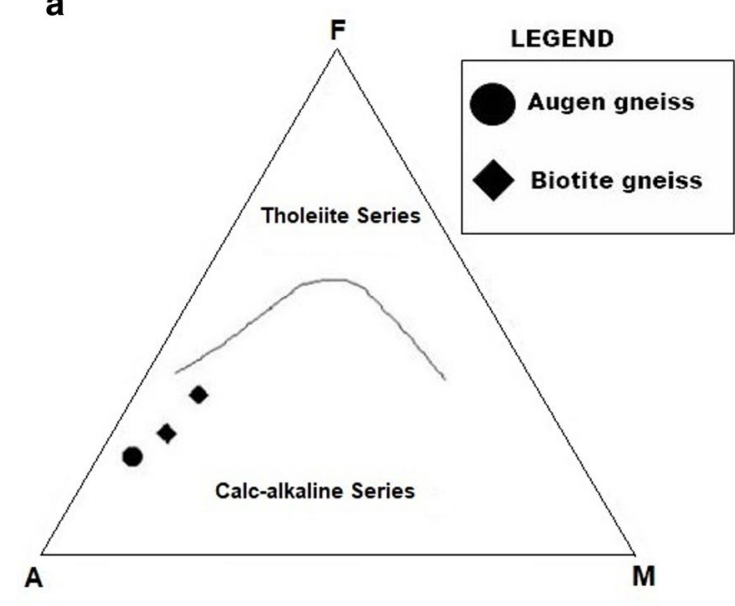

b

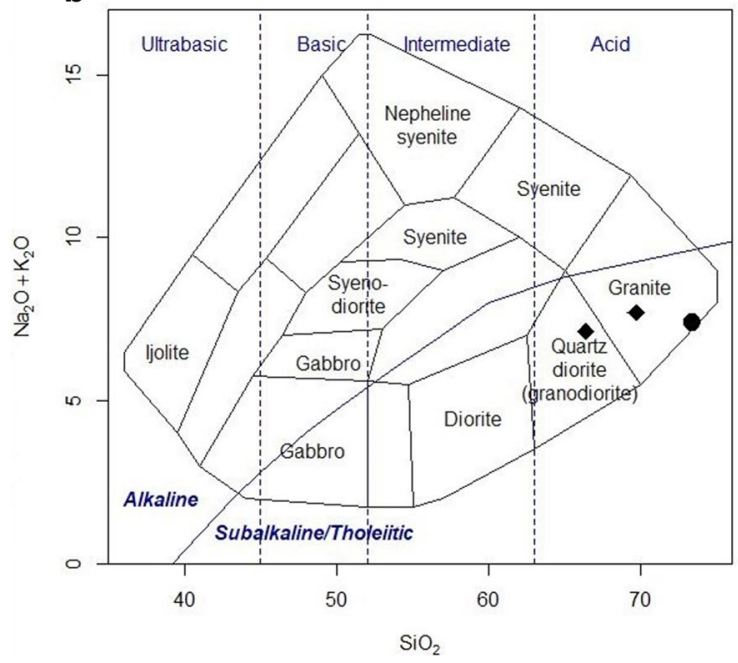

Fig. 15 Geochemical plots for the gneissic rocks in the study area showing a AFM plot for the gneissic rocks, after Irvine and Baragar [38]; $\mathrm{A}=\mathrm{Na}_{2} \mathrm{O}+\mathrm{K}_{2} \mathrm{O}, \mathrm{F}=\left(\mathrm{FeO}+\mathrm{Fe}_{2} \mathrm{O}_{3}\right)$ and $\mathrm{M}=\mathrm{MgO} ; \mathbf{b}$ TAS classification diagram for the gneissic rocks, after Cox et al. [26]

joints and fractures in the quartzite are evidence of highstrain metamorphism in the quartzitic rocks. According to Boggs and Boggs [31], basins are created by the rifting of continental plates for the deposition of sediments. The breakup of Rodinia Supercontinent accompanied by opening of Mozambique Ocean that occurred about 800-850 Ma further created many basins for the deposition of sediments $[2,11,12]$. The sediments which filled the basins are inferred to include granitic sandstone which is the possible protolith of the quartzite. These sediments were deposited in a passive margin basin in the West African Craton (WAC). There was intense reworking of sediments to accumulate quartz in order to eliminate the labile minerals. This later formed a quartz arenite sandstone after burial, compaction and lithification processes. According to Kroner and Stern [11,12], ocean closures and plate collision resulted in the formation of Gondwana and its related convergent plate activities. The oblique collision between the Benin Nigerian Shield and the West African Craton accompanied by wrench faulting and anatectic doming caused the metamorphism and deformation of rocks in such areas. This process metamorphosed the quartz arenite into a quartzite. The deformation from the collision may have created foliations and the undulating surface observed in the quartzite. The two lithologic precursors later experienced further deformation. The continuous 
Fig. 16 Geotectonic discrimination plot for the gneisses, after Pearce et al. [27]
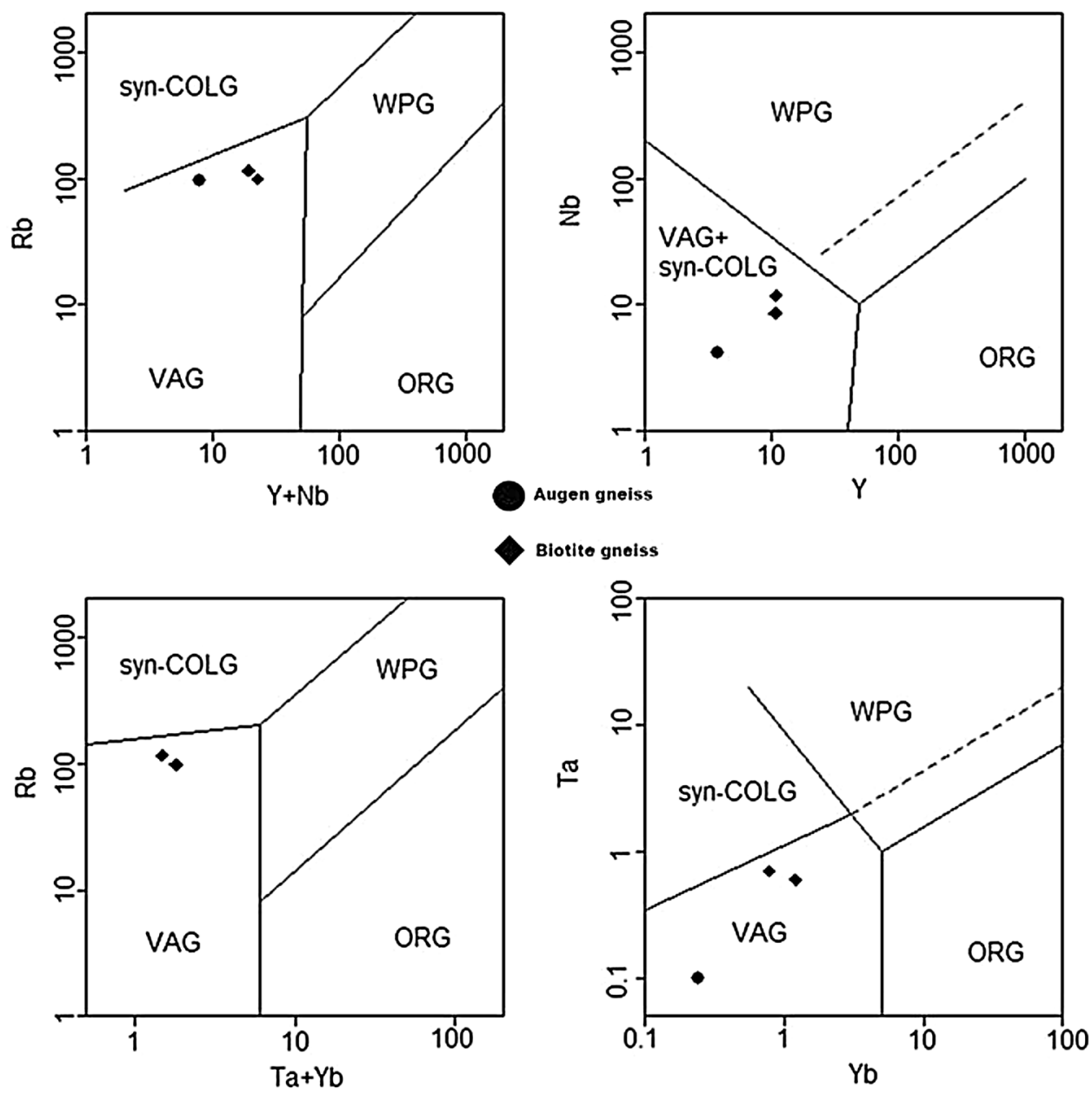

burial activities at deeper crustal levels resulted in the formation of ductile deformational features such as foliations followed by brittle deformation at shallow crustal levels. Based on the inferences made on the ages of the lithologies in the study area with respect to the field observations and data gathered, the rocks found in the study area were proposed to have a general geodynamic evolution based on the structural data, field relationship and geochemical data obtained from the field work. A simplified geodynamic evolution of the local geology can be inferred from the petrography and geochemistry of the rocks as well as the structural relationships between the rocks, and it is given as follows: (a) emplacement of granitic magmatic bodies of granitic and granodioritic basement of the Archaean which forms the rocks of the cratonic blocks that were involved in the collision, (b) an initial tectonic activity metamorphoses the magmatic bodies into gneissic terrain and creates basin at deeper crustal level through subsidence enabling the deposition of arenaceous sediments eroded from the granitic and gneissic basement, (c) the basement, together with the deposited sediments (sandstone), was then metamorphosed probably by the Pan-African Orogeny converting the sandstone into quartzite. However, the uppermost part of the sandstone was preserved and (d) an uplift of the rocks to shallow crustal level due to the collision resulted into brittle deformation and the thrusting of the Togo structural unit onto that of the Dahomeyan.

\section{Conclusion}

The general lithologies in the study area are quartzites, biotite and granitic gneisses based on critical field data collected. The laboratory work was characterised by geochemistry and thin-section analysis, and this provided much evidence and interpretation of data of changes that have taken place in the rocks of study area. The quartzites observed were inferred to belong to the Togo Structural Unit, while the gneisses belonged to the Dahomeyan basement unit. The various structures of joints, foliations, quartz veins and fractures observed in the study area are indications that the rocks have been subjected to high degrees of brittle, ductile deformation 

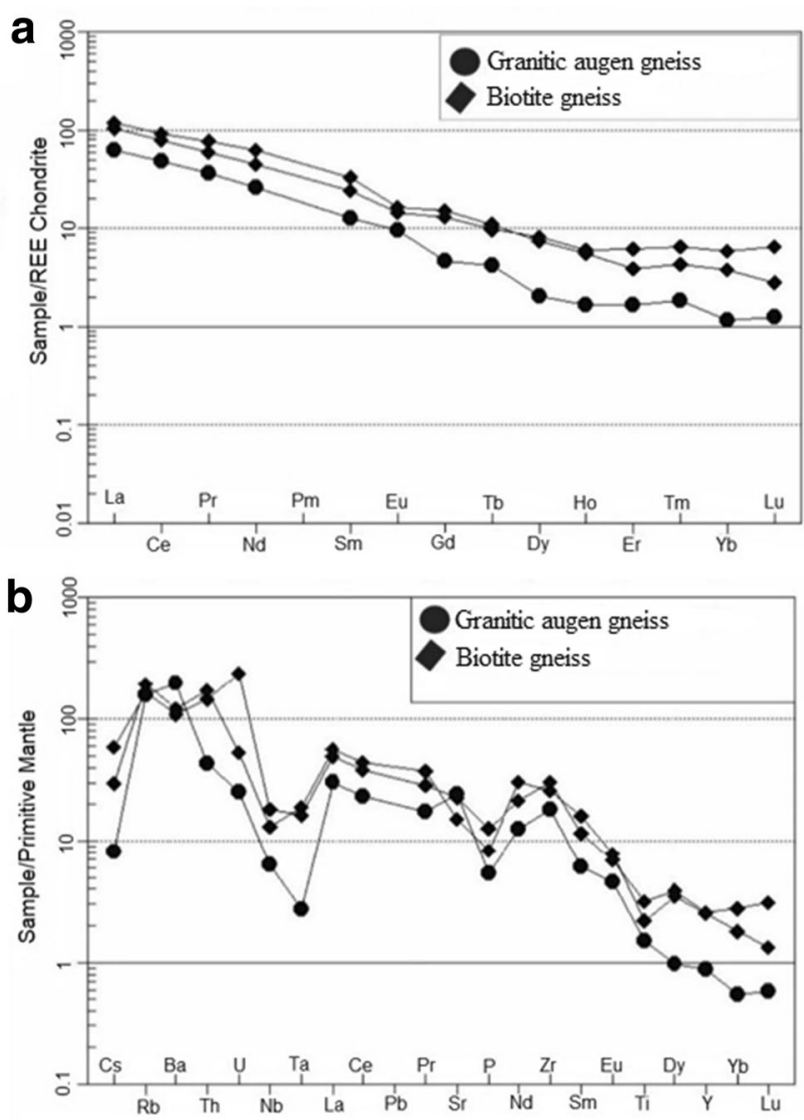

Fig. 17 Geochemical plots for the gneiss in the study area; a normalised REE chondrite plot for the gneissic samples, after Boynton [28], b normalised primitive mantle plot for the gneissic samples, after McDonough and Sun [30]

and metamorphism. The high degree of deformation and metamorphism of the rocks are associated with the collisional activities that occurred during the Pan-African Orogenic event 600 million years ago. The quartzites in the Togo Structural Unit are most likely to be from a granitic protolith, probably arenaceous sandstone. The gneiss is also believed to be from a granitic protolith. The Togo Structural Unit rocks are less deformed as compared to those in the Dahomeyan. Therefore, based on the inferences made from previous studies on the regional neoproterozoic Pan-African Orogenic event in Ghana, the petrographic, structural and geochemical observations made from this study clearly indicate that the neoproterozoic Pan-African Orogenic event in Ghana resulted from deformation (collision), deposition of arenaceous sediments (sandstone) which metamorphosed into quartzites by the Pan-African Orogeny. These tectonic events eventually led to an uplift of the rocks to shallow crustal level due to the collision resulted in brittle deformation and the thrusting of the Togo structural unit onto that of the Dahomeyan.
Acknowledgements The authors deeply acknowledge the Department of Earth Science, University of Ghana, for providing facilities of research work. One of the authors (J. A. A. Darko) would also like to thank Professor P. M. Nude, Dr. Prince Ofori Amponsah and all the lecturers of the Earth Science department for their immense support and guidance throughout field study. The authors are finally thankful to other anonymous reviewers for their critical comments and suggestions in enhancing the quality of the paper.

\section{Compliance with ethical standards}

Conflict of interest The authors declare that they have no conflict of interest.

\section{References}

1. Nude PM, Kwayisi D, Taki NA, Kutu JM, Anani CY, BanoengYakubo B, Asiedu DK (2015) Petrography and chemical evidence for multi-stage emplacement of western Buem volcanic rocks in the Dahomeyide orogenic belt, southeastern Ghana, West Africa. J Afr Earth Sci 112:314-327

2. Jarrar GH, Theye T, Yaseen N, Whitehouse M, Pease V, Passchier CJPR (2013) Geochemistry and P-T-t evolution of the Abu-Barqa Metamorphic Suite, SW Jordan, and implications for the tectonics of the northern Arabian-Nubian Shield. Precambr Res 239:56-78

3. Dewey JF, Shackleton RM, Chengfa C, Yiyin S (1988) The tectonic evolution of the Tibetan Plateau. Philos Trans R Soc Lond A 327(1594):379-413

4. McRivette MW, Yin A, Chen X, Gehrels GE (2019) Cenozoic basin evolution of the central Tibetan plateau as constrained by U-Pb detrital zircon geochronology, sandstone petrology, and fissiontrack thermochronology. Tectonophysics 751:150-179

5. Attoh K, Dallmeyer R, Affaton P (1997) Chronology of nappe assembly in the Pan-African Dahomeyide orogen, West Africa: evidence from 40Ar39Ar mineral ages. Precambr Res 82(1-2):153-171

6. Kroner A (2017) Pan-African mobile belts as evidence for a transitional tectonic regime from intraplate orogeny to plate margin orogeny. In: Evolution and mineralization of the Arabian-Nubian shield: proceedings of a symposium convened by Ahmad MS Al-Shanti, Elsevier, p 21

7. Nude PM, Shervais JW, Attoh K, Vetter SK, Barton C (2009) Petrology and geochemistry of nepheline syenite and related carbonate-rich rocks in the Pan-African Dahomeyide orogen, southeastern Ghana, West Africa. J Afr Earth Sci 55(3-4):147-157

8. Tairou MS, Affaton P, Anum S, Fleury TJ (2012) Pan-African paleostresses and reactivation of the Eburnean basement complex in Southeast Ghana (West Africa). J Geol Res. https://doi. org/10.1155/2012/938927

9. Kesse GO (1985) The mineral and rock resources of Ghana. A.A. Balkema Press, Rotterdam, Boston

10. Twite F, Broughton D, Nex P, Kinnaird J, Gilchrist G, Edwards D (2019) Lithostratigraphic and structural controls on sulphide mineralisation at the Kamoa copper deposit, Democratic Republic of Congo. J Afr Earth Sc 151:212-224

11. Kroner A, Stern R (2004) Pan-African orogeny. Encycl Geol 1:1-12

12. Lascelles DF (2006) The Mt Gibson banded iron formation hosted magnetite deposit: two distinct processes for the origin of high grade iron ore deposits. Econ Geol 101:651-666

13. Kwayisi D, Agra NA, Dampare SB, Asiedu DK, Amponsah PO, Nude PM (2017) Two suites of gabbros in the Buem Structural Unit, of the Pan-African Dahomeyide orogen, southeastern 
Ghana: constraints from new field and geochemical data. J Afr Earth Sci 129:45-55

14. Attoh K, Nude PM (2008) Tectonic significance of carbonatite and ultrahigh-pressure rocks in the Pan-African Dahomeyide suture zone, southeastern Ghana. Geol Soc Lond Spec Publ 297(1):217-231

15. Herron MM (1988) Geochemical classification of terrigenous sands and shales from core or log data. J Sediment Res 58(5):820-829

16. Roser B, Korsch R (1986) Determination of tectonic setting of sandstone-mudstone suites using content and ratio. J Geol 94(5):635-650

17. Roser B, Korsch R (1988) Provenance signatures of sandstonemudstone suites determined using discriminant function analysis of major-element data. Chem Geol 67(1-2):119-139

18. Osae S, Asiedu DK, Banoeng-Yakubo B, Koeberl C, Dampare SB (2006) Provenance and tectonic setting of Late Proterozoic Buem sandstones of southeastern Ghana: evidence from geochemistry and detrital modes. J Afr Earth Sci 44(1):85-96

19. Dickinson WR (2013) Laboratory of geotectonics, Department of geosciences. Proven Arenites 148:333

20. Mondal NC, Singh V, Sankaran S (2011) Groundwater flow model for a tannery belt in southern India. JWater Resour Prot 3(02):85

21. Ejeh OI, Akpoborie IA, Etobro Al (2015) Heavy minerals and geochemical characteristics of sandstones as indices of provenance and source area tectonics of the Ogwashi-Asaba Formation, Niger Delta Basin. Open J Geol 5(08):562

22. Werner C (1987) Saxonian granulites-igneous or lithogenous. A contribution to the geochemical diagnosis of the original rocks in high-metamorphic complexes. Contributions to the geology of the Saxonian granulite massif (Sächsisches Granulitgebirge). Zfl Mitt 133:221-250

23. Mackenzie FT, Garrels R (1971) Evolution of sedimentary rocks. Norton, New York

24. Winter JD (2007) An introduction to igneous and metamorphic petrology. Academic Internet Publications, Oxford

25. Gill JB (2012) Orogenic andesites and plate tectonics, vol 16. Springer, Berlin
26. Cox K, Bell J, Pankhurst R (1979) The interpretation of igneous rocks. George Allen and Unwin, London

27. Pearce JA, Harris NB, Tindle AG (1984) Trace element discrimination diagrams for the tectonic interpretation of granitic rocks. J Petrol 25(4):956-983

28. Boynton WV (1984) Cosmochemistry of the rare earth elements: meteorite studies. In: Developments in geochemistry, vol 2. Elsevier, pp 63-114

29. Rollinson HR (1993) Using geochemical data: evaluation. Presentation, interpretation Singapore Ongman

30. McDonough WF, Sun S-S (1995) The composition of the Earth. Chem Geol 120(3-4):223-253

31. Boggs S Jr, Boggs S (2009) Petrology of sedimentary rocks. Cambridge University Press, Cambridge

32. Feybesse J-L, Milési J-P (1994) The archaean/proterozoic contact zone in West Africa: a mountain belt of décollement thrusting and folding on a continental margin related to $2.1 \mathrm{Ga}$ convergence of Archaean cratons? Precamb Res 69(1-4):199-227

33. Attoh K (1990) Dahomeyides of Southeastern Ghana: evidence for oceanic closure and crustal imbrication in a Pan-African orogen. Publication occasionnelle du CIFEG, BRGM, Orleans $\operatorname{Tr}(21)$

34. Ghana-Geological-Survey (2009) Geological map of Ghana1:1,000,000. Geological Survey Department, Accra, Ghana

35. Taylor SR, McLennan SM (1995) The geochemical evolution of the continental crust. Rev Geophys 33(2):241-265

36. Weaver B, Tarney J (1984) Major and trace element composition of the continental lithosphere. Phys Chem Earth 15:39-68

37. Shao J, Yang $S$ (2012) Does chemical index of alteration (CIA) reflect silicate weathering and monsoonal climate in the Changjiang River basin? Chin Sci Bull 57(10):1178-1187

38. Irvine T, Baragar W (1971) A guide to the chemical classification of the common volcanic rocks. Can J Earth Sci 8(5):523-548

Publisher's Note Springer Nature remains neutral with regard to jurisdictional claims in published maps and institutional affiliations. 